\title{
ECONOMIC ANALYSIS OF LEGAL REGULATIONS REGARDING LIABILITY FOR LOSS RESULTING FROM A DANGEROUS PRODUCT
}

\author{
JOANNA KUŹMICKA-SULIKOWSKA*
}

\section{INTRODUCTION}

The present article pertains to certain aspects of liability for loss caused by a dangerous product within the context of economic analysis of relevant legal regulations. The idea of the necessity of the existence of liability in compensation for loss caused by products (consumption goods) which have turned out to be dangerous to life, health or property does not, in principle, raise any objections. Liability regimes within the aforementioned scope have been formed within the frameworks of individual legal orders, be it upon the intervention of the legislator or activity of the courts. A real turning point for the legal orders of EU member states in this respect was EEC Directive No. 374/85 of 25 July 1985 on the approximation of the laws, regulations and administrative provisions of Member States concerning liability for defective products ${ }^{1}$. The process of implementing the Directive into national legal orders resulted in far-reaching standardisation of liability regimes for loss caused by dangerous products; however, differences exist between the legal solutions in force in individual countries. As this falls outside of the scope of the present work, readers are referred to the relevant literature ${ }^{2}$. Here we should do no more than make a general ascertainment that the aforementioned liability regime for loss caused by a dangerous product is commonly considered to be tort liability ${ }^{3}$

DOI: 10.2478/wrlae-2013-0005

* PhD in Law, Assistant Professor at the Department of Civil Law and International Private Law at the Faculty of Law, Administration and Economics, University of Wroclaw; attorney-at-law; j.kuzmicka@.prawo.uni.wroc.pl

1 OJ L985.210.29. For more information on the significance of this directive see $M$ Jagielska in A Olejniczak (ed), System Prawa Prywatnego, vol. 6, Prawo zobowiazań część ogólna (CH Beck 2009) 881-888.

${ }^{2}$ See eg: Ch von Bar, The Common European Law of Torts, vol. 2, Damage and Damages, Liability for and without Personal Misconduct, Causality and Defences (Clarendon Press 2005) 418-424; M Jagielska (n 1) 888; J. Kuźmicka - Sulikowska, Odpowiedzialność deliktowa $w$ prawie wybranych państw obcych (Prawnicza i Ekonomiczna Biblioteka Cyfrowa 2011) 58-66, 192-200, 283-290.

${ }^{3}$ Eg Ch von Bar (n 1) 418; M Jagielska, Podstawy odpowiedzialności za produkt (CH Beck 2004) 45; W Dubis in E Gniewek (ed) Kodeks cywilny. Komentarz (CH Beck 2006) 767; B Gnela, Odpowiedzialność za szkode wyrzadzona przez produkt niebezpieczny (tzw. 
and will be analysed as such. Therefore, issues associated with other potential sources of liability will remain outside of the scope of the present discussion, including contractual liability of the seller towards the purchaser.

Furthermore, it should be emphasised that the dominant point of view in doctrine is that liability for loss caused by a dangerous product is based on the risk principle ${ }^{4}$. This is no different from the situation in English legal doctrine, where it is agreed that liability for loss caused by dangerous products is based on the strict liability principle, and as such is independent of the culpability element concerning the product's manufacturer's ${ }^{5}$. Such close attention has been paid to English law as it is the context in which the position was formulated that the practice of law is often out of step with theory; this is attributed to courts' frequent practice of comparing the costs which would be incurred to make a product less dangerous with the expected costs of an accident. This constitutes a modified application of Hand's formula, which would dictate that a given case of liability in tort is in fact based on the fault principle ${ }^{6}$. However, this conclusion, despite such practice, seems unwarranted, particularly in light of legal regulations presently in force. Essentially, the fundamental assumptions consider such liability to be strict, independent of any

odpowiedzialność za produkt), (Zakamycze 2000) 281; P Granecki, ‘Odpowiedzialność za szkodę wyrządzoną przez produkt niebezpieczny - charakter i miejsce w systemie odpowiedzialności odszkodowawczej' (2001) 1 Przegląd Legislacyjny 32; Z Banaszczyk in K Pietrzykowski (ed) Kodeks cywilny, vol. I, Komentarz do artykułów 1-44911 (CH Beck 2008) 1473; MO Brzozowska, 'Cywilnoprawna odpowiedzialność za produkt niebezpieczny' in C Banasiński (ed) Standardy wspólnotowe $w$ polskim prawie ochrony konsumenta (Prawo i Praktyka Gospodarcza 2004) 224; E Łętowska, Ochrona niektórych praw konsumentów. Komentarz (CH Beck 2001) 124; C Czech-Śmiałkowski, 'O odpowiedzialności za produkt' (2002) 1 Radca Prawny 53; F Mohmand, 'Pojęcie produktu niebezpiecznego w rozumieniu przepisów kodeksu cywilnego o odpowiedzialności za produkt' in M Pyziak - Szafnicka (ed) Odpowiedzialność cywilna. Księga pamiatkowa ku czci prof. A. Szpunara, (Zakamycze 2004) 142. Although it should be pointed out that there are rare points of view that this is not liability in tort, but a new liability in compensation regime (such as eg $\mathrm{Cz}$ Żuławska in G Bieniek (ed) Komentarz do kodeksu cywilnego, Księga trzecia, Zobowiązania, vol. I, (Wydawnictwo Prawnicze LexisNexis 2003) 463. See also: Z. Strus, 'Odpowiedzialność za szkodę wyrządzoną przez produkt niebezpieczny' (2001) 1-2 Palestra 24-25.

4 Jagielska (n 1) 911 and 'Odpowiedzialność za produkt' (2000) 8 Monitor Prawniczy 495; M Safjan, 'Naprawienie krzywdy niemajątkowej w ramach odpowiedzialności ex contractu' in Pyziak - Szafnicka (ed) (n 3) 277; Dubis (n 3) 767; Banaszczyk (n 3), 1476; E Bagińska, 'Nowe unormowanie odpowiedzialności cywilnej za produkt' (2000) 9 Przegląd Sądowy 40; Czech-Śmiałkowski (n 3) 58; J Rajski, 'Odpowiedzialność za produkt niebezpieczny w świetle nowych przepisów kodeksu cywilnego' (2001) 1 Przegląd Prawa Handlowego 23, 25. For a different approach: P Granecki who seeks a new principle, namely the principle of absolute risk (P Granecki, 'Odpowiedzialność za szkodę wyrządzoną przez produkt niebezpieczny - charakter i miejsce w systemie odpowiedzialności odszkodowawczej' (2001) 1 Przegląd Legislacyjny 33).

${ }^{5}$ V Harpwood, Modern Tort Law (Routledge-Cavendish 2009) 342; D Oughton, J Marston, B Harvey, J Lowry, Law of Torts (Oxford University Press 2005) 68; P Giliker, S Beckwith, Tort (Sweet \& Maxwell 2004) 258; J Hodgson, J Lewthwaite, Tort Law (Oxford University Press 2004) 433; S Hedley, Tort (LexisNexis 2004) 99; M Lunney, K Oliphant, Tort Law. Text and Materials (Oxford University Press 2003) 539; WVH Rogers, Winfield and Jolowicz on Tort (Sweet \& Maxwell 2002) 352-353; BA Hepple, MH Matthews, Tort : Cases and Materials (Butterworth \& Co (Publishers) Ltd 1991) 504.

${ }^{6}$ R A Posner, Economic Analysis of Law, 5th ed (Aspen Publishers 1998) 197. 
culpability element, taken into account on fulfilment of objective premises. As such, assuming a marginal or even complete lack of knowledge by potential victims of the danger posed by a product to which they are exposed, a situation will arise in which the manufacturer of the product, aware of the broad scope of his liability, will include the possible costs into the price of the product. For this reason, protection afforded by the legislator to victims of dangerous goods through ensuring compensation not only for damage to chattels but also for personal injuries is justified. Thus we should consider whether the legal solution currently in effect is economically efficient, or rather if economic analysis of law would lead us to be more inclined to adopt a liability structure based on a different principle.

Due to the profile of the work, comments included within the article will focus on legal aspects and deliberations concerning economic analysis presented in the relevant literature, and as such will constitute the basis for conclusions addressing the legal regulations. In respect of detailed mathematical analysis, readers are referred to other literature treating this subject ${ }^{7}$.

\section{SIGNIFICANCE OF THE LIABILITY PRINCIPLE IN THE CONTEXT OF ECONOMIC ANALYSIS}

Within the framework of economic analysis of law, concepts associated with liability for damage caused by dangerous products are mostly considered as particular cases of liability in which the activity of the parties play a crucial role; this activity is defined as the production of given goods by manufacturers and the quantity of purchases made by the aggrieved.

In such settings, some authors conclude upon completing detailed economic analyses that, regardless of the level of carefulness within the scope of the activities of both producers and potentially aggrieved, the number of producers operating on the market as well as their production outputs are set at an efficient and economically effective level regardless of the liability principle assumed. Their argument in support of this standpoint is that if producers possess knowledge about the danger associated with their goods, the expected costs of compensation are included in the prices of the products which they sell. In such cases, liability based on the risk principle (strict liability) results in the price of goods reflecting above and beyond manufacturing and trading costs the full burden of the potential compensation which the producer may have to pay for damage caused by the dangerous characteristics of the product. On the other hand, in respect of buyers (potentially aggrieved), this will result in a reduction of their purchases. Under liability based on the fault principle (in the form of negligence), the price will constitute a reflection of the equilibrium within the scope of allocation of compensation costs. Going further, assuming a lack of producer liability, the price will be affected by production costs but

\footnotetext{
7 See for example: R Cooter, T Ulen, Ekonomiczna analiza prawa (J Bełdowski, J Czabański, K Metelska-Szaniawska, M Olender, B Targański (CH Beck 2009) 490 - 494.
} 
not any factored-in risk; however, consumers will still purchase the product at a price calculated to account for full $\operatorname{costs}^{8}$. The above statements primarily stem from the fact that in an equilibrious system the price of goods is not affected by manufacturers' nor consumers' expenditures on prevention and precaution. Thus, neither when applying the risk principle nor in the absence of manufacturer liability does a mechanism which would stimulate both parties to observe appropriate levels of carefulness emerge. In the case of the risk principle, the potentially aggrieved will not behave in this way due to the fact that they will receive compensation from the manufacturer regardless of their own actions. On the other hand, manufacturer, when he will be unburdened by legal liability in accordance with the law regulations, will not exhibit increased carefulness in the process of designing and manufacturing goods as there are no economic incentives to reduce the probability that damage will occur. Only liability based on the fault principle inclines both producers and potentially aggrieved to behave with due caution ${ }^{9}$.

However, R. Posner opposes the point of view presented above, as in his view the risk principle may also lead to economically efficient solutions. According to Posner, in a situation where liability is based on this principle, the manufacturer, aware of the fact that liability may be assigned to him despite the absence of fault on his part, will make sure to provide highest level of product safety as well as to minimise the damage potentially caused by the product. He will incorporate the associated costs into the price of the goods, which means that they will increase. This will, in turn, lead consumers to purchase the appropriate quantity of products, and the associated danger will not be subject to their assessment; furthermore, in most cases they will not even be aware of it, as the burden of reducing it will rest with the manufacturer ${ }^{10}$. However, if the principle of fault is assumed, inclining manufacturers to observe an appropriate level of carefulness, it will be the consumers who bear the burden of the damage unless they themselves also observe such carefulness. Underestimation by consumers of the dangers associated with the possible harmful influence of a given product will lead to that product's overconsumption. On the other hand, overestimation will lead to an excessive drop in consumption. Furthermore, considering the latter liability principle, a significant obstacle exists for the aggrieved associated with the necessity to prove fault on the part of the producer, which may be very difficult to accomplish, especially when it comes to technologically complex manufacturing processes. These arguments seem to speak strongly in favour of basing liability for damage caused by a dangerous product on the principle of risk. Interestingly, however, R. Posner provides another alternative solution to this legal issue by reversing the aforementioned mechanisms and making knowledge regarding the dangers associated with each product available to consumers. This would consist in recognising that consumers should generally assume that every product carries a certain danger, be it larger or smaller; this would in turn imply the concept of liability in compensation, accepting that the

\footnotetext{
${ }^{8}$ TJ Miceli, Economics of the law. Torts, contracts, property, litigation (Oxford University Press 1997), 29-30.

${ }^{9}$ ibid 31-32.

${ }^{10}$ Posner (n 6) 198.
} 
aggrieved entities hold an a priori assumption regarding a specific level of the risk of damage being caused by products of a given type (assumption of risk).

Proponents of an intermediate point of view ${ }^{11}$ in relation to the positions presented above assume that recognition of one or the other principle as optimal (meaning economically efficient) within the scope of liability for damage caused by dangerous products depends on a range of diverse circumstances, which may lead to contradictory rulings from time to time. The fundamental factors taken into account here are ones such as perunit costs of production, the probability of an accident occurring and causing damage as a result, and the scope of such damage if it occurs. However, viewpoints with regard to the role of the liability principle may be distinguished once other elements are accounted for, such as consumers' knowledge about the risk associated with a given product, their attitude to this risk or the possibilities of undertaking risk-reducing measures. Accordingly, in an ideal situation where the consumer's knowledge regarding the danger associated with the purchased product is complete, on the grounds of the risk principle the manufacturer bears liability in compensation in every case of damage caused to those purchasing their products; consumers make purchases at the appropriate level, taking into consideration the fact that the price is set in a manner reflecting all the costs associated with the product. Risk as a principle of manufacturers' liability therefore leads to an efficient level of production output, as well as to an efficient level of measures undertaken by manufacturers to protect against damage caused by the goods they supply to the market. The same result in both these spheres is achieved by making manufacturers' liability dependent on their fault. In such cases, producers will strive to manufacture products which are safe enough to comply with the criteria of appropriate carefulness as defined by the courts (assuming these are determined in accordance with principles of economic efficiency). On the other hand, consumers, aware that manufacturers are acting in such a manner and aware of the possible consequences facing them in the form of costs associated with the incurred damage, will be inclined to purchase products which are more expensive to the extent that the higher price reflects an appropriately higher level of product safety and the ensuing lower risk of it causing damage. As a result, the value of purchases made by consumers remains at an optimal level. Interestingly, it is considered that, for analogous reasons, releasing producers from liability will also lead to efficient levels of output and carefulness. With consumers adopting a neutral approach to risk and possessing perfect knowledge about it, it seems that the choice of a liability principle or a lack of liability is an irrelevant factor in stimulating the appropriate level of carefulness and output. Nevertheless, the assumption of perfect knowledge by the consumer about a product is idealistic, as such a state does not exist in practice. Usually the buyer's knowledge regarding a given product is more or less limited, if for no other reason than due to limited access to information about the manufacturing process, lack of information as to the harmful effects of its individual components or

${ }^{11}$ AM Polinsky, An introduction to Law and Economics (Aspen Publishers 2003) 114-121. 
insufficient time and means to carry out detailed tests of the properties of all purchased products. Naturally, consumers' knowledge in these areas will be imperfect. Thus one should consider whether this significantly influences the effects of the legislator's choice of one liability principle or another. As it turns out, consumers' degree of knowledge regarding the risk posed by a product does not change the situation if manufacturer's liability is based on the principle of risk. It will be the latter who is always responsible for the damage, therefore the expected costs associated with compensation claims will be included in the price of manufactured goods. Thus, the quantity of purchases will still be determined by this price, and not an element in the form of a dangerous characteristic of the product, as consumers, presented with certain compensation for damage from the manufacturer will approach the product as though it was entirely safe, regardless of its actual parameters $^{12}$. According to those who hold such a view, that is why differences will only become apparent on the basis of the fault principle. While manufacturers are also motivated in this case to maintain an appropriate level of carefulness as a means of protection against the requirement to pay compensation, buyers possessing insufficient knowledge about the product will not properly estimate the associated risks and the probability of incurring damage as a result of its use; this will lead to an excessive level of purchases and the resulting inefficient outcome. Risk underestimation by consumers and excessive level of purchases may also be caused by excluding manufacturer liability for damage caused to the environment. What is more, freed from the risk of bearing costs associated with compensation payments, manufacturers will not observe caution in the production process, which is another socially undesirable outcome. Taking into consideration a situation which typically occurs in trade, meaning one where the customer's knowledge regarding a product and the associated risks is incomplete, only the risk principle allows for an efficient outcome both in respect of the level of carefulness applied by the manufacturer as well as of setting an optimal level of output. However, one should bear in mind that all the above deliberations are accompanied by an unchanging assumption of a neutral risk attitude on the part of producers and consumers, but this factor is extremely significant in the context of social and economic consequences stemming from liability principles. These consequences will be different in the case of a risk-averse attitude, and as a result will be closely linked with the availability and scope of insurance policies. Considering the matter in the broadest sense possible, if there are no possibilities for insurance, then basing liability for damage caused by dangerous products on the risk principle will better serve those consumers who are risk averse assuming a neutral stance by manufacturers, whereas a neutral stance of consumers and a protective approach by the manufacturers will function better on the grounds of liability dependent upon the fault element or in the absence of liability. The attitude of both of these categories of entities towards acceptance of bearing risk associated with danger inherent to products does not play any role in liability principles if full insurance protection is guaranteed, as then a proper allocation of risk occurs regardless of whether manufacturers' liability is based on the

\footnotetext{
${ }^{12}$ However, one may raise serious objections against such an assertion if put in the context of potential injuries or even life-threatening risks.
} 
principle of risk, of fault, or if it is not determined. In an intermediate situation, when insurance policies are available that do not ensure complete coverage for damage caused by dangerous products, then under the risk principle part of the damage will be covered by the insurer and part by manufacturers, but the interests of the aggrieved are fully protected. However, adopting the principle of fault will lead to a situation where, if the manufacturers are freed from liability by observing an appropriate level of carefulness, then the need to cover costs associated with damage incurred due to a product will be split between the aggrieved and that party's insurer. Thus, depending on whether customers or producers are more averse to incurring risk and the danger of damage, the more adequate solution will be to base liability respectively on the principle of risk or fault (potentially the assumption of a lack of liability on the part of the manufacturer, as within the scope of risk allocation this leads to results analogous to those of the fault principle). Within the scope of the position under discussion here, a final significant factor to be taken into account in evaluating liability principles for a product is that, apart from producers, it is also consumers potentially aggrieved - who are able to undertake precautions which can lead to a reduction or even an elimination of the risk of incurring damage as a result of the dangerous properties of a given product. The level of carefulness observed by consumers is, for obvious reasons, of particular significance within the boundaries of the principle of fault and principle of risk, but modified in such a way as to take into account the charge of aggrieved contribution. On the grounds of the former principle, as already demonstrated, producers will strive to avoid paying compensation by maintaining an appropriate level of carefulness in their actions, which will result in the weight of the damage being borne by the property of the aggrieved, especially if the scope of risk is not correctly estimated and the aggrieved does not undertake appropriate precautions nor insure himself against such an event. However, the opposing standpoint, that is basing manufacturer liability on the principle of risk with the possibility of a release from the obligation to pay compensation if it is demonstrated that the damage is a result of culpability on the part of the aggrieved, provides the latter with powerful motivation to maintain appropriate precautions in order to avoid the charge of contributing to the occurrence of damage and to receive compensation from the manufacturer. If the aggrieved does not observe appropriate carefulness, underestimating the risk posed by the dangerous properties of the purchased product and the probability of damage incurred, then he will have to struggle by himself to make good the damage to his property, especially considering that he will not see the need to insure against such. The manufacturer, however, will have no reason to act in a careful manner and minimise the risk associated with the products he manufactures. Thus, even in a situation where the effects of the level of carefulness are taken into account within the scope of the actions of the aggrieved in respect of the shaping of the size of the risk posed by the product, incorrect evaluation by the aggrieved of the risk of actually incurring damage on that account will block the desired effects in respect of economic efficiency and within the scope of the parties' carefulness levels or risk allocation, regardless of whether the manufacturer's liability is based 
on the principle of fault or risk with a charge of contribution by the aggrieved $^{13}$.

Similarly, R. Cooter and T. Ulen point out that not only the observance of precautions by the manufacturer should be taken into account, but also by the aggrieved. They remark that the mechanism for causing damage by dangerous products seems on first glance to fit the unilateral carefulness model, where only the damage perpetrator has the ability to undertake precautions in order to reduce the risk of occurrence of damage and the aggrieved has no such possibility. In the context of the present analysis it is, first and foremost, the manufacturer who appears to be able to undertake measures reducing the danger posed by the product due to the fact that he controls the design and manufacturing process thereof. If one was to assume that only the manufacturer has the ability to undertake such precautionary measures, then a solution where the manufacturer's liability in tort is based on the risk principle should be regarded as economically efficient. In the opinion of the aforementioned authors, this is the most efficient principle in light of economic analysis of law within the framework of situations reflecting unilateral carefulness models. They do remark, however, that in the example under discussion one may observe certain characteristics appropriate to the bilateral carefulness model: the potentially aggrieved, and in particular product users, are not devoid of options when it comes to reducing the probability of accidents occurring, for example by using products according to the manual, observing manufacturers' recommendations etc. In respect of the above, $\mathrm{R}$. Cooter and T. Ulen emphasise that from the point of view of economic analysis of law it seems justified to adopt an intermediate solution, located between treating a case of liability in compensation for damage caused by a dangerous product as an example of unilateral carefulness (where they recognise the risk principle as economically efficient) and bilateral carefulness (and the associated preference for basing manufacturer's liability on the principle of fault as the most efficient solution). In fact, they propose a solution imposing liability on the manufacturer based on the risk principle, but within the scope of damage incurred by the aggrieved as a result of design faults or faults occurring during manufacture, or within the scope of warnings regarding possible dangerous properties of the product (e.g. lack of warnings or incomplete information). However, in the opinion of the aforementioned authors the manufacturer should be released from liability in compensation in a situation where the aggrieved voluntarily took on the risk of incurring damage or used the product in an incorrect manner. Stipulating such possibilities for releasing the manufacturers from liability would also include the aforementioned possibility of the aggrieved undertaking certain precautions. In the event of the legislator choosing not to stipulate these two possibilities for releasing the manufacturer from the burden of liability, the latter would be forced into the extensive use of insurance mechanisms, leading to increased prices for consumers (including cautious ones), which would be an inefficient solution ${ }^{14}$.

However, most of the above comments pertain to a situation where the aggrieved entity is the direct purchaser of the product, as only then may

\footnotetext{
${ }^{13}$ Polinsky (n 11) 114-121.

${ }^{14}$ Cooter, Ulen (n 7) 491-492.
} 
one sensibly take into account the element of estimating risk associated with the product involved in a given transaction. The result is the very frequent omission of a very significant scope of damage caused by dangerous products, namely that affecting third parties totally unrelated to the contractual relationship concerning the sale of a given product, its manufacturer and distributors. Essentially, the legal regulations of individual EU states, reflecting the solution included in the aforementioned directive, also protect so-called by-standers, that is persons who did not purchase the product but did incur damage due the effects of its dangerous properties. This may pertain to, for example, the members of the household of somebody who purchased a dangerous product, guests, but also a random person who, as a result of unfortunate circumstances, found himself impacted by the dangerous effects of the product and as a result incurred negative consequences in the form of damage or injury. Few authors broach this subject at all, indicating that in such cases it seems more appropriate to apply liability based on the risk principle (strict liability) that on the fault principle (negligence), as only against the backdrop of the former is the asking price of the product calculated taking into account all possible costs which the manufacturer (or another entity deemed liable by the law) can be faced with as a result thereof; this includes the expected damages incurred by the aforementioned third parties as a result of accidents caused by the product. However, this aspect does not affect the shaping of the price of a given good in the event of manufacturer liability being based on the fault principle, as liability can be avoided by behaving with appropriate carefulness reflecting the standards required by the courts; by doing so, the manufacturer is not burdened by the obligation to compensate for damage incurred by other entities, and thus does not has to include such costs in the prices of products. This, however, encourages high levels of demand, which in turn leads to excessive production ${ }^{15}$.

In this context one objection should be highlighted which is also related to the scope of liability for damage caused by a dangerous product. It does not pertain to the group of persons potentially aggrieved, but rather to the group of entities the weight of discharging the compensation claims rests upon, as in light of current regulations it is not only the manufacturer who bears liability in compensation when the cause of an occurrence of damage was a dangerous product. The group of legally liable entities also includes the producer of raw materials and individual components, the quasimanufacturer (meaning the nominal manufacturer, that is the one whose name, brand name or other distinguishing mark is on the given product even if that entity did not in fact manufacture the product), the product's importer, and under certain conditions its seller, who may avoid liability by indicating either the actual or nominal manufacturer, or even the importer of a given product (see Article $449^{5}$ of the Polish Civil Code). This very complex web of liable entities ${ }^{16}$ is usually omitted in the course of economic

\footnotetext{
${ }^{15}$ Polinsky (n 11) 121.

${ }^{16}$ For more details see: J Kuźmicka, 'Zakres podmiotowy obowiązywania przepisów o odpowiedzialności za szkodę wyrządzoną przez produkt niebezpieczny’ in P Machnikowski (ed) Odpowiedzialność $w$ prawie cywilnym, Acta Universitatis Wratislaviensis $\mathrm{Nr} 2897$,
} 
analysis of the legal regulations concerning liability for damage caused by a dangerous product. In this respect the conducted analyses do not encompass the true form of this liability, including the possibility of particular entities taking into account the fact that the obligation to compensate for damage will not necessarily be assigned solely to them. However, it should be realised that performing analysis with consideration of the multiplicity of these entities as well as the structures of their respective liabilities (e.g. see Article $449^{5} \S 3-5$ of the Polish Civil Code), with the number of the possible combinations that may arise in practice, would be a strenuously difficult task. For this to be at all possible, it would entail incredibly detailed deliberations unfavourable for drawing conclusions of a general enough character to serve as the basis for conclusions regarding generally applicable legal regulations. For such practical reasons it seems that economic analyses carried out taking into account the manufacturer should also be applied with a large dose of prudence to other entities liable for damage caused by a dangerous product.

\section{CONCLUSION}

A review of reports on economic analysis of regulations pertaining to liability for damage caused by dangerous products indicates that research efforts focus both on assessment of whether normative solutions are economically efficient, as well as development by the use of economic tools and proposals for more socially beneficial solutions (assuming those already employed are assessed negatively in that context). Both positive and normative economic analysis is therefore carried out. The former includes explanations of the results of the application of the provisions of law in society (including the issue of whether they are economically efficient) and research on the legitimacy of legal practice (within the scope of this article, this predominantly means adjudication by the courts of cases involving compensation claims) alongside interpretation of specified provisions by the use of economic tools, with particular emphasis on costs associated with the functioning of individual legal institutions. Here it is frequently sought to demonstrate that the legal solutions in force meet the economic efficiency criterion, leading to increased social wealth in both the tangible and intangible sense, whereas in the normative aspect of economic analysis, the fundamental assumption is taken to be that law should be economically efficient, and thus the object of interest is whether a given legal solution may cause socially undesirable outcomes and whether the relevant regulatory institutions and methods are adequate for achieving their intended goals. If they are not, it is then assessed what modifications to the regulations would comply with this requirement and lead to economically efficient solutions, including to the increase of social wealth ${ }^{17}$. Positive

Prawo CCC (Wydawnictwo Uniwersytetu Wrocławskiego 2006) 197; Czech-Śmiałkowski (n 3) 54-55.

${ }^{17}$ Posner (n 6), 26-29; J Stelmach in J Stelmach, R Sarkowicz, Filozofia prawa XIX i XX wieku (Wydawnictwo Uniwersytetu Jagiellońskiego 1999) 185-186; RT Stroiński, 'Ekonomiczna analiza prawa czyli w poszukiwaniu efektywności' (2002) 3 Kwartalnik Prawa Prywatnego 551 and 'Wprowadzenie do ekonomicznej analizy prawa (Law and 
economic analysis is thus descriptive, it relates the actual effects of individual legal provisions and attempts to demonstrate the economic efficiency of the law, whereas normative analysis provides a critical point of view and assists in developing legal solutions optimal for achieving particular goals in a manner favourable to rational and more conscious decisions at the stage of creating legislation. The deliberations of the article show that various conclusions arrived at on the basis of economic analysis within this area of interest are radically different. Points of view seeking an adequate - from the perspective of economic analysis of law - solution in liability for damage caused by dangerous products based on the principle of risk may also be supported by the fact that most of the doctrine favours basing such liability on exactly this principle, and in particular on axiological considerations in favour of this solution, also applicable during the course of the legislative process. As a fundamental legislative motive for introducing liability based on the principle of risk in the event of damage caused in a given set of circumstances, including in particular in the event of damage caused by a dangerous product (as well as, for example, by the activity of an enterprise powered by forces of nature) the cuius commodum eius periculum (damnum) or ubi emolumentum ibi onus ${ }^{18}$ rule is often cited. In this manner the idea is expressed according to which the party which benefits from a particular activity should also bear liability in compensation for possible damage caused by it. The actions themselves undertaken by a given entity are legal, and they may be socially or economically useful, but nonetheless they carry the specific risk of causing damage to the legallyprotected property of other entities. That is why it is argued that those who undertake such activity with the aim of receiving certain material benefits do so at their own risk. This risk also includes the fact that they may bear liability in compensation for damage which, due to their activity (in the event in question as a result of coming into contact with products manufactured and marketed by them) may be incurred by others ${ }^{19}$. This directly relates to the liability regime for damage resulting from a dangerous product. The manufacture of various types of products is required for the

Economics)' in M Bednarski, J Wilkin (eds) Ekonomia dla prawników i nie tylko (Wydawnictwo Prawnicze Lexis Nexis 2nd ed, 2005) 476; BH Bix, A Dictionary of Legal Theory (Oxford University Press 2004) 115-116; JM Kelly, Historia zachodniej teorii prawa (WAM 2006) 468-470; M Wierzbicki, 'Ekonomiczna szkoła prawa' in J Zajadło (ed) Leksykon współczesnej teorii i filozofii prawa (CH Beck 2007) 63; J Oniszczuk, Filozofia i teoria prawa (CH Beck 2008) 585-588. The latter author demonstrates in detail that the subject of interest of economic analysis is work on the causes and consequences of legal regulations, their justification, and predicting in what way legal entities will react to particular regulations. Thus, research conducted within this scope mainly aspires to: "1) explanation of the effects of the rule of law on the behaviour of entities, 2) illustration of the establishment or existence of individual legal regulations, 3) design of rules and legal institutions for attaining particular goals, 4) assessment (testing, control) of rules and legal institutions, 5) interpretation of particular legal concepts."

${ }^{18}$ W Warkałło, Prawo i ryzyko (Ministerstwo Pracy i Opieki Społecznej 1949) 15; J Szachułowicz, Odpowiedzialność deliktowa przedsiębiorstw państwowych wprawianych $w$ ruch siłami przyrody (Wydawnictwo Prawnicze 1968) 3.

${ }^{19}$ M Kaliński in A Olejniczak (ed) System Prawa Prywatnego, t. 6, Prawo zobowiazań część ogólna (CH Beck 2009) 61; A Śmieja in A Olejniczak (ed) System Prawa Prywatnego, t. 6, Prawo zobowiązań - część ogólna (CH Beck 2009) 555. 
functioning of society; it would be impossible to do without some of them. However, due to their dangerous properties (e.g. a flaw in design, production or instructions, use of a harmful substance, etc.) they may cause damage. The manufacturer which benefits from the sale of such a product is naturally considered the entity which bears liability for damage caused by this product. Such a rule of liability, despite being severe, is considered to be fair, especially that the boundaries of liability are clearly defined here by indicating a number of exonerating circumstances, the demonstration of which leads to the release of the manufacturer from liability (see in particular Art. $449^{3}$ of the Polish Civil Code). Other restrictions to this liability are also foreseen (e.g. $449^{2}$ or Art. $449^{7}$ of the Polish Civil Code) ${ }^{20}$. A more detailed review of the related concepts exceed the scope of the present work.

To sum up the discussion, it should be also pointed out that in applying the method of economic analysis of regulations pertaining to torts, it is assumed that it should aim at the motivation of actors through particular legal solutions which would lead to the number of torts they commit stabilizing at an economically efficient level. This, in turn, will lead to a desirable levelling of marginal social costs (that is, costs associated with undertaking activities with the aim of preventing or at least reducing torts, or reducing the administrative costs of such activities as court proceedings) with marginal social benefits (mainly understood as the scope of damage avoided). Such a state of equilibrium would be disturbed by both increasing and decreasing any of these values by even one unit. Socially undesirable consequences would ensue, such as costs exceeding benefits.

However, a much more significant conclusion stemming from the deliberations in this article seems to be that the economic analysis of tort law assumes the requirement to accept a given level of "allowable" torts in everyday life. It should be emphasised that while the introduction of a legal provision which would prohibit activities posing a risk of causing damage is possible per se, this would lead in many cases to absurd results, negative social outcomes and an unimaginable increase in the cost of society's functioning. This is particularly evident in the case of activities which are necessary or useful for the functioning of a society. Therefore, in relation to socially desirable activities, the aim of economic analysis of law is not the elimination of torts, but their socially optimal limitation, by which a positive result is attained in the form of a retention of such activities that are socially necessary but carry a risk of causing damage; the assumed reduction leads to a balancing of the benefits stemming from them and their costs. As is evident from the discussion, in developing such a state of equilibrium in respect of liability for damage caused by a dangerous product, the principle on which the liability is based is crucial. It seems that this conclusion may be applied to other regulations concerning the liability in tort regime.

\footnotetext{
${ }^{20}$ There are arguments in favour of the introduction of regulations excluding overly severe obligations to pay compensation in respect of entities profiting from activity which poses a risk of causing damage to other entities as long as such activity is valuable to society, particularly by J Łopuski, 'Odpowiedzialność za szkody wyrządzone w związku z użyciem sił przyrody (art. 152 k.z.): jej znaczenie i ewolucja w perspektywie minionego 70 - lecia' (2004) 3 Kwartalnik Prawa Prywatnego 673.
} 
Despite the unquestionable value of subjecting legal solutions to evaluation through the prism of economic analysis, it should be stated that assessing regulation within the scope of liability in tort, including liability for damage caused by dangerous products, as well as the potential postulating of de lege ferenda solutions in this area based solely on economic analysis of law does not seem to be justified; this is because doing so would result in an overly one-sided assessment, considering only economic factors and omitting others of at least equal significance. Furthermore, it does not seem right for the lawmaking process to be guided solely by conclusions stemming from economic analysis of law, particularly considering that there are significant differences in points of view in this area, as was indicated in the course of the discussion. Nevertheless, it is beyond doubt that economic analysis of law may be a very useful tool for a rational legislator. 